\title{
Absenteeism for low back pain in the municipal administration of Goiânia in the years 2008 and 2009
}

\author{
Absenteísmo por lombalgia na prefeitura de \\ Goiânia nos anos de 2008 e 2009
}

\author{
Cristina Aparecida Neves Ribeiro ${ }^{[a]}$, Demóstenes Moreira ${ }^{[b]}$ \\ [a] MSc, Universidade de Brasília, Brasília, DF - Brazil, e-mail: crisnevesfisio@hotmail.com \\ [b] PhD, professor, Universidade de Brasília, Brasília, DF - Brazil, e-mail: demostenes@terra.com.br
}

\begin{abstract}
Objective: To establish and evaluate the indicators of absenteeism for low back pain among municipal public servants of the city of Goiania in 2008 and 2009. Material and methods: This is a descriptive, epidemiological, retrospective study. We used secondary data provided by the Municipal Medical Board of Goiânia. The sample was composed by active, statutory and commissioned civil servants of the executive branch, of both sexes, who took sick leaves for health care in the period from January 2008 to December 2009. We analyzed all cases of sick leave for health care which were taken for a period of more than 3 days and caused by low back pain. Frequency and severity indexes, proportion of lost time and average length of absences were calculated. The data were statistically analyzed using descriptive and inferential statistics. Results: 625 sick leaves were analyzed. In 2008, 32\% of public servants took sick leave for health care. $2.83 \%$ of these leaves were for low back pain, generating 3541 days of absence. In 2009, the total percentage of sick leaves was 30\%. 5.38\% of these were due to low back pain, leading to 6890 lost working days. The indicators of absenteeism for 2008 and 2009 were, respectively: frequency index $=0.009$ and 0.015 ; severity index $=0.14$ and 0.26 , proportion of lost time $=13.89 \%$ and $27.34 \%$; average length of absences $=16.39$ and 16.84 days . Conclusion: The results indicate the need for the creation of intervention policies on work organization, since low back pain is a disorder that can be prevented at the primary level.
\end{abstract}

Keywords: Low back pain. Absenteeism. Public sector. Occupational health. Health profile. 


\section{Resumo}

Objetivo: Estabelecer e avaliar os indicadores de absenteísmo por lombalgia entre os servidores públicos municipais da cidade de Goiânia nos anos de 2008 e 2009. Material e métodos: Estudo retrospectivo, descritivo, de caráter epidemiológico realizado na Junta Médica Municipal de Goiânia. A amostra foi composta por todos os servidores públicos municipais ativos do poder executivo, de ambos os gêneros, civis estatutários e comissionados afastados por licença para tratamento de saúde no período de janeiro de 2008 a dezembro de 2009. Foram analisadas as Licenças Tratamento Saúde superiores a três dias ocasionadas por lombalgia e calculados os índices de frequência, gravidade, proporção de tempo perdido e a duração média das ausências. Os dados foram tratados estatisticamente, por meio de análise descritiva e inferencial. Resultados: Foram analisados 625 afastamentos. Em 2008, 32\% dos servidores afastaram-se por Licença Tratamento Saúde e destes 2,83\%, por lombalgia, gerando 3541 dias de ausência. Em 2009, o percentual total de afastamentos por doença foi de 30\% e destes 5,38\% aconteceu por lombalgia levando a 6890 dias de trabalho perdidos. Os indicadores de absenteísmo foram respectivamente para 2008 e 2009: índice de frequência =0,009 e 0,015; índice de gravidade = 0,14 e 0,26; proporção de tempo perdido = 13,89\% e 27,34\%; duração média das ausências = 16,39 e 16,84 dias. Conclusão: Os resultados apontam para a necessidade de criação de políticas de intervenção sobre a organização do trabalho, pois a lombalgia é uma afecção passível de prevenção em nível primário.

Palavras-chave: Dor lombar. Absenteísmo. Setor público. Saúde do trabalhador. Perfil de saúde.

\section{Introduction}

In 2007, there were approximately 8.5 million public servants at all levels of government in Brazil. A study conducted by the Institute for Applied Economic Research (IPEA) indicated that public employment, considering direct and indirect administration and state enterprises, accounted for about 11\% of the total number of employed persons between the years 1995 and 2005. And, within this amount, the majority works at municipal level, which shows a clear increasing trend (1).

This category of workers is directly involved in the preparation of projects and provision of various services to the population, especially in the areas of education and health. Thus, they play an important role in Brazilian society. Nevertheless, there is still not much information on this social segment, especially from the point of view of labor relations and sickness (2).

Public servants do not differ at all from other classes of employees in what regards their susceptibility to acquire a disease or to have a disease aggravated by work. According to Schilling's classification, there are two groups of occupational diseases: category II are diseases to which work is a contributory factor; and category III are pre-existing disorders or diseases for which work is a causing or aggravating factor. They are represented by arterial hypertension, chronic respiratory diseases, mental disorders and diseases of the locomotor system (3).

This last group of diseases includes back pain, osteoarthrosis, cervicobrachialgias, tenosynovitis, among others. All of them are important causes of morbidity and have a great social and economic impact. However, low back pain can be highlighted due to its high prevalence (4). It is defined as pain and discomfort in the region located between the margin of the last rib and the gluteal folds, with or without radiation to the legs (5).

A large number of people suffers from low back pain. A systematic review found point prevalences ranging from $12 \%$ to $33 \%$. These figures increased when the whole life period of the individual was studied, ranging from $11 \%$ to $84 \%$ (6). Consequent social costs are high and the aggravating factor is that a small number of persons affected by low back pain generate excessive costs, besides the loss of several days of work. Therefore, once added up, its direct and indirect expenses amount to an alarming proportion, when compared to other pathologies (7).

A significant share of expenditures is due to the loss of working days, which is known as absenteeism (8). A study conducted by the European Foundation for the Improvement of Living and 
Working Conditions (9) defined the concept of absenteeism as: "... temporary, prolonged or permanent disability to work as a result of disease or infirmity...". Absenteeism due to illness is the most common cause of absenteeism among the working population and has negative repercussions for employees, employers and, consequently, for the whole society (9).

Given the above, the aim of this study was to establish and evaluate the indicators for absenteeism due to low back pain among municipal public servants of the city of Goiania in 2008 and 2009.

\section{Material and methods}

This is a descriptive, epidemiological, retrospective study on absenteeism for low back pain among municipal public servants of the city of Goiania in the period from January 2008 to December 2009.

The study sample was composed of cases of sick leave for health care (SLHC) for a period of more than three days, for active puclic servants of both sexes who were permanent workers, permanent workers on probation, or commissioners of secretariats, agencies and companies of the municipal executive power. All leaves have to be certified by the Municipal Medical Board (MMB).

We used secondary data provided by the MMB, where all absenteeism for more than three days related to the municipal executive power must be registered. The information regarding the registration of the public servant, the reason for the SLHC and the number of absence days were collected from books of manual records. The Goiânia Urbanization Company (COMURG) and the Metropolitan Company for Collective Transportation services of Goiânia (CMTC) were excluded from the study because almost all of its staff members are employees hired under the Consolidation Work Laws (CLT) regime. The list of all organs and entities included in the study is shown in Table 1.

Our goal was to analyze sickness absenteeism. Therefore, all absenteeism due to maternity leave, leave due to illness in the family and other types of leaves that public servants are entitled to take according to their statute were excluded from the analysis. As the object of study here are low back pain cases, we included in the study all SLHC with the codes M54; M54.3; M54.4; M54.5; M54.9.

Table 1 - List of bodies and entities of the municipal executive power included in the study

(To be continued)

\begin{tabular}{ll}
\hline \multicolumn{1}{c}{ Bodies and entities of the municipal executive power } \\
\hline Direct administration & Indirect administration \\
\hline Municipal Government Secretariat (SEGOV) & Municipal Agency for Traffic, Transportation and Mobility (AMT) \\
Municipal Communication Secretariat (SECOM) & Municipal Urban Constructions Agency (AMOB) \\
Municipal General Procuratorate (PGM) & Municipal Environment Agency (AMMA) \\
Municipal Secretariat of Planning and Urbanism (SEPLAM) & $\begin{array}{l}\text { Social Security Institute for Municipal Public Servants } \\
\text { of Goiânia (IPSM) }\end{array}$ \\
$\begin{array}{l}\text { Municipal Health Secretariat (SMS) } \\
\text { Institute for Health and Social Care of Municipal Public Servants } \\
\text { of Goiânia (IMAS) }\end{array}$ \\
$\begin{array}{l}\text { Municipal Secretariat of Administration and Human } \\
\text { (COMDATA) }\end{array}$ \\
$\begin{array}{l}\text { Mesources (SMARH) } \\
\text { Municipal Secretariat of Finances (SEFIN) }\end{array}$ \\
$\begin{array}{l}\text { Municipal Secretariat of Labor, Employment and } \\
\text { Earnings (SETRAB) }\end{array}$ \\
$\begin{array}{l}\text { Municipal Education Secretariat (SME) } \\
\text { Municipal Housing Secretariat (SMHAB) }\end{array}$ \\
\end{tabular}


Table 1 - List of bodies and entities of the municipal executive power included in the study

\begin{tabular}{l}
\hline \multicolumn{1}{c}{ Bodies and entities of the municipal executive power } \\
\hline Direct administration \\
\hline Municipal Culture Secretariat (SECULT) \\
Municipal Secretariat for Economic Development (SEDEM) \\
Municipal Tourism Secretariat (SEMTUR) \\
Municipal Infrastructure Secretariat (SEINFRA) \\
Municipal Secretariat for Sports and Leisure (SEMEL) \\
Municipal Secretariat of Social Assistance (SEMAS)
\end{tabular}

Source: Goiânia. Lei complementar n. 183 de 19 de dezembro de 2008.

Two dependent variables were created: number of sick leaves (events or cases) and number of absence days. For the study of absenteeism, we used the recommendations of the Subcommittee on Absenteeism of the International Society for Occupational Health (10), addressing three indicators represented by the following formulas:

Frequency Index $=\frac{\text { Number of sick leaves per year }}{\text { Number of public servants (average annual number) }}$ Severity Index $=\frac{\text { Number of lost days per year }}{\begin{array}{l}\text { Number of public servants (average } \\ \text { annual number) }\end{array}}$

Proportion of lost time $=\frac{\text { Number of lost days per year }}{\begin{array}{l}\text { Expected number of working days } \\ \text { per year }\end{array}}$

Moreover, due to its importance, another indicator by Quick and Lapertosa (11) was used:

Average length of absences $=\frac{\text { Number of lost days per year }}{\text { Number of sick leaves per year }}$

The data were statistically analyzed using descriptive and inferential statistics. The research followed the ethical guidelines outlined in Resolution 196/96 of the National Health Council. The research project was approved by the Research Ethics Committee of the Faculty of Health Sciences of the University of Brasilia (Opinion number 046/10). To protect the confidentiality of those involved in the study, we changed the functional number by the order number. All authors declare that there was no conflict of interest in this study.

\section{Results}

In both years surveyed a total number of 650 SLHC occurred due to low back pain. We collected data regarding 625 sick leaves of 482 public servants, who had been absent for 10,431 days. Twenty five records of SLHC were excluded from the sample because not all variables could be extracted due to inconsistencies in the system, which probably resulted from the fact that the data were not completely filled in.

In 2008, the average population among the sites studied was 23,846 public servants. They generated 7,625 SLHC, with a percentage of $32 \%$ of cases of sick leave and the loss of 173,859 days of work. Of these, $181(2.83 \%)$ public servants took sick leaves from work for low back pain, generating 216 cases of sick leave (given the fact that the same person may have taken sick leave more than once). This amounted for a total of 3,541 days of absence.

Analyzing the proposed indicators in Table 2, it can be seen that the frequency index was low, which was expected, mainly because we selected only one condition from a very large set of diseases that can lead to sick leaves.

On the other hand, the severity index, the proportion of lost time and the average length of absences 
showed values that deserve to be highlighted and will be discussed later.

The following year, the average population increased to 25,496 public servants. Even with the increase in the population studied, the percentage of people who took SLHC did not rise. On the contrary, it was slightly lower, accounting for $30 \%$ of cases of sick leave, 7596 occurrences of SLHC and the loss of 204,235 days of work. Conversely, the number of cases of sick leave for low back pain increased to 409 (5.38\%). These were generated by 301 people and caused the loss of 6,890 working days.

The frequency index remained low. However, the severity index, the proportion of lost time and the average length of absences were even higher, as can be seen in Table 2. We highlight the proportion of lost time, which went from $13.89 \%$ in 2008 to $27.34 \%$ in 2009.

These indicators of absenteeism were also calculated according to each evaluated secretariat (Table 3), except for the frequency index, which was not relevant to the analysis because its results were all lower than 0.05 .
Of the 22 agencies studied, four (SEMTUR, SEMEL, SECOM and IMAS) had no records of sick leave for low back pain in two consecutive years. This fact calls into question the possibility of underreporting, i.e., there may have been episodes of low back pain, but they did not generate SLHC.

The SEMAS, which has a large number of employees working in functions that fall into the category operational service, showed the highest severity index and the highest average length of absences in 2008.

The COMDATA is a body responsible for data processing, thus, administrative functions are prevalent. It showed the highest severity index and the third highest average length of absences in 2009.

Regarding the proportion of lost time, the two secretariats with the highest rates were those of education and health, respectively. It is important to highlight that the figures found in these two secretariats are quite superior to those found in other organs or entities. This reveals that in these two organs the relation between the number of lost days and the expected number of working days is compromised due to episodes of low back pain.

Table 2 - Indicators of absenteeism among municipal public servants on leave due to low back pain in the years 2008 and 2009 in Goiânia

\begin{tabular}{llllllll}
\hline Year & $\begin{array}{l}\text { Total population } \\
\text { (annual average) }\end{array}$ & $\begin{array}{l}\text { Number of sick } \\
\text { leaves for low } \\
\text { back pain }\end{array}$ & $\begin{array}{l}\text { Number of days } \\
\text { of sick leave for } \\
\text { low back pain }\end{array}$ & $\begin{array}{l}\text { Frequency } \\
\text { index }\end{array}$ & $\begin{array}{l}\text { Severity } \\
\text { index }\end{array}$ & $\begin{array}{l}\text { Proportion } \\
\text { of lost time }\end{array}$ & $\begin{array}{l}\text { Average } \\
\text { length of } \\
\text { absences }\end{array}$ \\
\hline 2008 & 23846 & 216 & 3541 & 0.009 & 0.15 & 13.89 & 16.39 \\
2009 & 25496 & 409 & 6890 & 0.016 & 0.27 & 27.34 & 16.84 \\
\hline
\end{tabular}

Note: Proportion of lost time is expressed in \%; average length of absences is expressed in days.

Expected number of working days: $2008=255 ; 2009=252$.

Source: Research data.

Table 3 - Indicators of absenteeism due to low back pain according to each body and entity of the municipal Executive power of Goiânia in the years 2008 and 2009

(To be continued)

\begin{tabular}{|c|c|c|c|c|c|c|}
\hline \multirow[t]{2}{*}{ Bodies and entities } & \multicolumn{2}{|c|}{$\mathrm{SI}{ }^{*}$} & \multicolumn{2}{|c|}{$\%$ lost time ${ }^{* *}$} & \multicolumn{2}{|c|}{$\mathrm{ALA}^{* * *}$} \\
\hline & 2008 & 2009 & 2008 & 2009 & 2008 & 2009 \\
\hline SMS & 0.06 & 0.25 & 1.65 & 7.58 & 12.38 & 17.36 \\
\hline SME & 0.19 & 0.32 & 8.25 & 14.17 & 18.29 & 16.61 \\
\hline SECULT & 0 & 0.03 & 0 & 0.06 & 0 & 15 \\
\hline SEDEM & 0 & 0.05 & 0 & 0.04 & 0 & 5.5 \\
\hline
\end{tabular}


Table 3 - Indicators of absenteeism due to low back pain according to each body and entity of the municipal Executive power of Goiânia in the years 2008 and 2009

(Conclusion)

\begin{tabular}{|c|c|c|c|c|c|c|}
\hline \multirow[t]{2}{*}{ Bodies and entities } & \multicolumn{2}{|c|}{$\mathbf{S I ^ { * }}$} & \multicolumn{2}{|c|}{$\%$ lost time $e^{* *}$} & \multicolumn{2}{|c|}{$\mathrm{ALA}^{* * *}$} \\
\hline & 2008 & 2009 & 2008 & 2009 & 2008 & 2009 \\
\hline SEINFRA & 0.59 & 0.19 & 0.12 & 0.04 & 15 & 10 \\
\hline PGM & 0 & 0.07 & 0 & 0.04 & 0 & 10 \\
\hline SEMTUR & 0 & 0 & 0 & 0 & 0 & 0 \\
\hline SEMEL & 0 & 0 & 0 & 0 & 0 & 0 \\
\hline SECOM & 0 & 0 & 0 & 0 & 0 & 0 \\
\hline SMHAB & 0.32 & 0.24 & 0.12 & 0.10 & 7.5 & 12.5 \\
\hline SETRAB & 0.33 & 0 & 0.07 & 0 & 8.5 & 0 \\
\hline SEMAS & 0.61 & 0.38 & 1.61 & 1.19 & 24.12 & 17.59 \\
\hline SEFIN & 0.25 & 0.08 & 0.46 & 0.16 & 14.62 & 13.33 \\
\hline SEGOV & 0.05 & 0.07 & 0.10 & 0.11 & 12.5 & 14 \\
\hline SEPLAM & 0 & 0.05 & 0 & 0.06 & 0 & 15 \\
\hline SMARH & 0.07 & 0.12 & 0.39 & 0.79 & 14.28 & 13.33 \\
\hline AMOB & 0.21 & 0.43 & 0.49 & 1.13 & 15.5 & 12.95 \\
\hline AMMA & 0.30 & 0.34 & 0.41 & 0.53 & 8.15 & 13.5 \\
\hline IMAS & 0 & 0 & 0 & 0 & 0 & 0 \\
\hline COMDATA & 0.08 & 1.52 & 0.02 & 0.36 & 5 & 45 \\
\hline AMT & 0.14 & 0.45 & 0.20 & 0.73 & 13 & 46.25 \\
\hline IPSM & 0 & 1.09 & 0 & 0.24 & 0 & 60 \\
\hline
\end{tabular}

Note: ${ }^{\star} \mathrm{SI}=$ severity index; ${ }^{\star \star} \%$ lost time $=$ proportion of lost time; ${ }^{\star \star}{ }^{\star} \mathrm{ALA}=$ average length of absences.

Source: Research data.

It is also important to note that the situation of these two secretariats substantially deteriorated between 2008 and 2009. The rates of lost time more than quadrupled in the Health Secretariat in this period.

Regarding the number of absences per public servant, the vast majority - $83.97 \%$ and $76.41 \%$ in 2008 and 2009, respectively - was absent only once in each year of the study, as can be seen in Figure 1. Next, we present, in descending scale, the records of two to six sick leaves taken by the same public servant and for the same reason: back pain.

\section{Discussion}

Before deepening the discussion of these data, it is important to stress that only sick leaves longer than three days were analyzed in this study. Public servants may have used these days to take care of their own health, which may cause underreporting. In addition, we found a variety of methodological criteria that were used to establish the study sample in the national and international literature. This is due to the fact that the databases which support this type of study have diverse objectives and are organized differently. Thus, the comparisons and discussions presented below were based on the problems' context and not exclusively on the figures found.

On the percentage of sick leaves for low back pain, Ghaffari et al. (12) found similar results to this study. The authors reported $5 \%$ of sick leaves related to low back pain among a population of 18,031 Iranian industrial workers. In 2009, the municipal service of Goiania showed 5.38\% of sick leaves, including all professional categories. Thus, the reality found in this city is not really different from that reported internationally. 


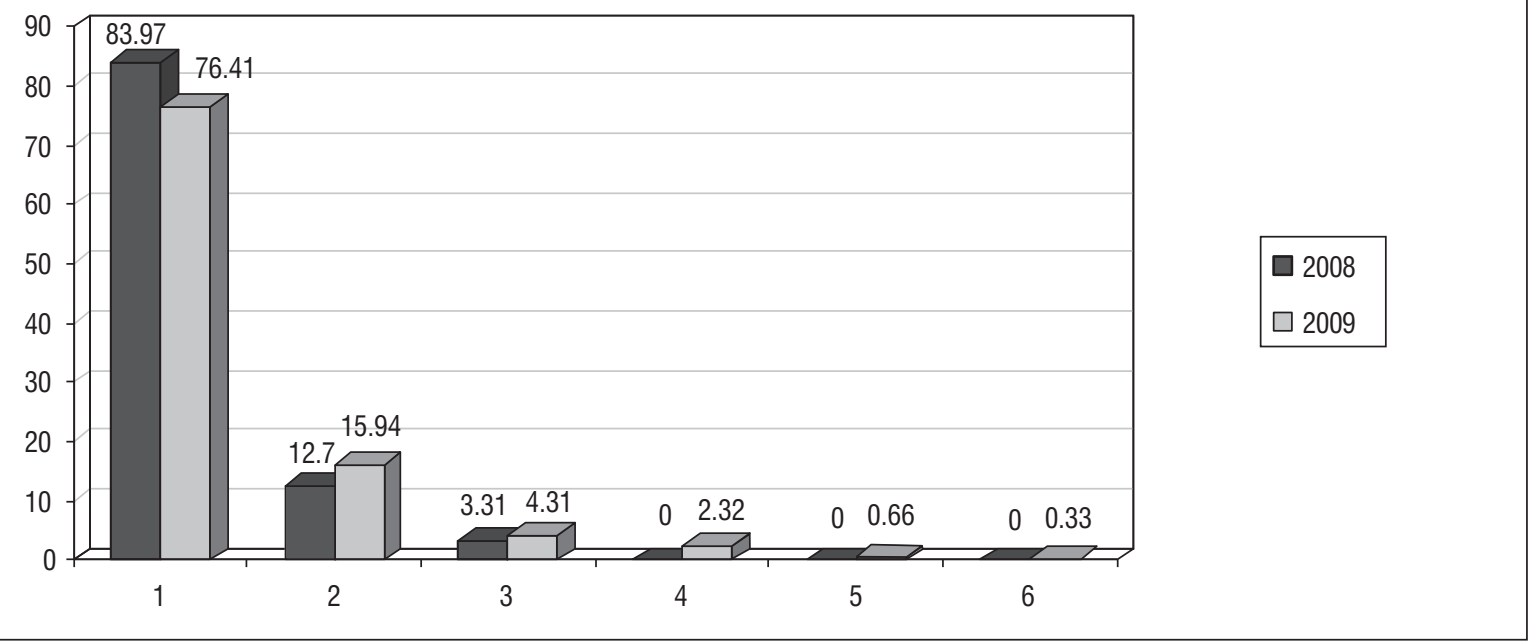

Figure 1 - Distribution of the number of absences per municipal public servant with SLHC for low back pain in the years 2008 and 2009 in Goiânia

Source: Research data.

A study conducted in order to investigate sickness absenteeism among public servants of Montevideo found: frequency index of 1.08; severity index of 6.84; and average length of absences of 6.28 days (13). Five hundred forty-one cases of sick leave registered in the medical service of a mining company in Peru were evaluated and the following indices were reported: frequency of 0.45 ; severity of 5.41; and average length of absences of 11.81 days. We compared our results with those found in the study conducted in Montevideo. Even though most figures are lower, we conclude that they are high, due to the loss of time and money caused by the absences (14). In the case of Goiânia, it is worth highlighting that the average length of sick leave for low back pain was 16 days, which is well above the results of the two studies previously mentioned.

A study conducted at Porto Alegre evaluated sick leaves longer than 15 days in all secretariats of the municipal government in 2004 and 2005. The average length of absences in 2004 was 21.1 days and the Municipal Secretary of Sports was the most affected entity (15). This rate was higher than that found in Goiania, probably due to methodological differences, since in this study we only considered sick leaves longer than three days. The severity indexes were 9.7 and 9.3 in 2004 and 2005, respectively (15). In Goiânia, the indexes found in 2008 and 2009 were 0.15 and 0.27 , respectively.
Still, in the study conducted in Porto Alegre, it was found that diseases of the musculoskeletal system and connective tissue represented the third cause of sick leaves among public servants. Of these, 16.1\% of absences were for back pain (CID M-54). Thus, it can be noticed that back pain has been responsible for a great number of absenteeism cases among the population studied (15).

A study with state bank employees conducted by Silva, Pinheiro and Sakurai (16) revealed an average length of absences of 24.78 days, considering all kinds of health problems. In this study, the average found was 16 days, however, we only considered cases of low back pain. If we take into account that some cases of convalescence and mental disorders result in longterm absences, we can see that the figures mentioned above are significant, because they represent only one of the diseases of the musculoskeletal system and connective tissue.

The average length of absences is an important indicator because the longer a person is absent from work for low back pain, the lower the treatment success rates and the greater the probability that such absence becomes longer. A systematic review found evidence of a strong relationship between long absences and lower chances of returning to work (17). Thus, prolonged absences need to be the target of further studies and a starting point for the implementation of ergonomic and educational practices. 
Regarding the proportion of lost time, we found that the Municipal Education Secretariat was the most affected in the municipal administration of Goiânia. This reality is reproduced in other cities: in Porto Alegre, the Education Secretariat had the third highest rate of sick leave (15).

In this study, The Municipal Health Secretariat ranked second in proportion of lost time. Illness among health professionals is not an irony, but a national reality. In São Paulo, diseases of the musculoskeletal system and connective tissue were the leading cause of absenteeism among workers of the Health Secretariat (18). In Santa Catarina, they were the second leading cause of absenteeism, and low back pain accounted for $16.27 \%$ of these cases (19).

Among the nurses of the basic healthcare network in Campinas, the proportion of time lost due to illness was 5.56\% in 2002 (20). In 2009, in the Health Secretariat of Goiânia, this proportion was $7.58 \%$ for all public health servants and only for back pain.

The area of health, and especially nursing, is the target of many studies of this kind. This is because it is well known that these professionals work under precarious conditions, with very high workloads (due to the fact that they usually have more than one job) and great emotional tension (because of the type of service provided) $(20,21,22)$.

The organs and entities studied showed heterogeneous results. Thus, we can infer that low back pain is most affecting those places where there is a greater association between risk factors and more susceptible people. Therefore, we suggest the implementation of different intervention policies for each secretariat.

Another indicator analyzed in this study was the number of times that a worker takes SLHC due to low back pain. This indicates symptom recurrence - considering the limitations of analysis, given the fact that one individual may have another pain episode and not take time off work. In this study, about a quarter of the sample had repeated SLHC.

This percentage is in accordance with a cohort study conducted by Stanton et al. (23), which evaluated 353 subjects who had had back pain, but had already been recovered for at least six weeks at the time of the study. After one year, approximately $25 \%$ of patients had recurrence of pain and risk factors could not be established.

The fact that most workers in this study only took one sick leave does not lead to the conclusion that the situation is not serious. A large number of cases of low back pain resolves quickly. Only a small number of cases - about $10 \%$ - becomes chronic. However, this small percentage is responsible for about $80 \%$ to $90 \%$ of social spending (24).

This is because cases of recurrent low back pain generate much higher direct and indirect financial costs than cases of first episodes. When treatment is not appropriate, the individual may have his functional capacity restricted, which translates into lower work performance and greater chance of taking another sick leave, with increasing periods of absence (25).

Recurrence is influenced both by physical and psychological factors. A systematic literature review found strong evidence that psychological factors contribute to the chronicity of low back pain. Grief, depression, mood swings and somatization showed association with worsening of low back pain (26).

This is confirmed by Gheldof et al. (27), who separately evaluated short- and long-term episodes of recurrence. In the first case, the psychological factor that determined the reappearance of symptoms was the fear to move around and aggravate the situation. In the second case, the dominant psychological factor was the severity of pain reported.

Strategies to reduce absenteeism have been studied and can serve as a basis for discussion and implementation among municipal public servants in Goiania. Steenstra et al. (28) conducted a randomized clinical trial in order to compare the effects on absences due to acute low back pain of an intervention program at the workplace. The control group received regular medical treatment and the study group additionaly received ergonomic modifications in the workplace. These interventions revealed significant results, especially among individuals over 44 years of age and with a previous history of sick leave. This was problaby because this group was more open to actively participate in the process of changes in the workplace.

Prevention still seems to be the best way to avoid or minimize this problem. Some authors suggest physical exercise and educational programs at work $(25,26,27,28,29)$. However, these measures should not be taken in isolation, but should be part of a biopsychosocial model which includes the worker and makes him/her aware of the importance of their participation (30).

Another interesting measure to decrease absenteeism is to create strategies to increase job 
satisfaction. This is because there is a relationship between high levels of satisfaction and lower absenteeism rates. Munch-Hansen et al. (31) conducted an observational study involving more than thirteen thousand public servants from 698 offices in Denmark. At the end, they identified a clear cause and effect relationship between psychosocial working conditions and absenteeism. Therefore, high levels of job satisfaction result in favorable working conditions and good occupational health.

It is important to emphasize that preventive measures can both prevent the appearance of new cases and decrease the chances of occurrence of the so-called "presenteeism", i.e., when a person goes to work despite feeling ill. This phenomenon also exists and is a risk factor for future absences, regardless of gender and of the type of employment (public or not) $(32,33)$.

According Caverley et al. (34), "presenteeism" will gradually replace absenteeism as an indicator of occupational health. The authors conducted a study at a public organization in Canada and found that workers went to work sick more often than they missed work due to illness. The most common reasons were: headache, back and neck pain, stomach discomfort, flus and colds.

Going sick to work has a high financial impact, according to a survey of costs for lost production time in the USA. Among the items surveyed, the biggest loss in productivity occurred in the form of "presenteeism". Estimated expenditures with production loss for LBP reach 7.4 billion dollars a year in this country (35).

The impact of absenteeism and "presenteeism" are so extensive that it is necessary to look at the problem from another standpoint, completely different from what most people are accustomed to. Only thus new discussions regarding occupational health can be started. What is the use of creating control measures for sick leaves if they are devoid of the appropriate prevention policies? What is the use of making a public servant participate in a workplace exercise program if the workplace is inappropriate? What is the use of organizing the work environment if social relationships are compromised?

\section{Conclusion}

We believe that the first step to be taken, within the universe studied here, is the discussion and planning of preventive policies based on a triad consisting of: work environment, social relations and the worker himself/herself. The discussion of production processes, their ergonomic arrangements and production techniques contextualized to the particular social relations of public service and the subjectivity of workers can have a positive long-term impact on illness.

Finally, it is important to understand that low rates of absenteeism do not indicate low rates of morbidity. Therefore, the frequency of absences for LBP was not high, but this does not mean that the risks (especially the ergonomic risks) are under control.

Furthermore, all general indicators of absenteeism increased from 2008 to 2009 , which evidences the need to perform a temporal sequence to establish the behavior of such data. The figures obtained in this study are sufficient to encourage a debate on the implementation of specific policies for the health of these public servants, especially if we take into consideration that low back pain is a disorder of predominantly mechanical origin and is preventable at the primary level.

\section{Acknowledgements}

Thanks to the Municipal Secretariat of Administration and Human Resources and the Municipal Medical Board of Goiânia for their permission to access the database used in this study and for providing logistical support to this research.

\section{References}

1. Instituto de Pesquisa Econômica Aplicada. Emprego público no Brasil: comparação internacional e evolução. Brasília: Ipea; 2009 (cited 2012 Apr 6). Available from: http://www.ipea.gov.br/portal/images/stories/PDFs/comunicado/090330_comunicadoipea19.pdf

2. Carneiro SAM. Saúde do trabalhador público: questão para a gestão de pessoas: a experiência na prefeitura de São Paulo. Rev Serv Publico. 2006;57(1):23-49.

3. Schilling RSF. More effective prevention in occupational health practice?. J Soc Occup Med. 1984;34(3):71-9. 
4. Mendes R. O impacto dos efeitos da ocupação sobre a saúde de trabalhadores: I - morbidade. Rev Saude Publica. 1988;22(4):311-26.

5. Airaksinen 0, Brox JI, Cedraschi C, Hildebrant J, KlaberMoffet J, Kovacs F, et al. Chapter 4: European guidelines for the management of chronic nonspecific low back pain. Eur Spine J. 2006;15(Suppl. 2):S192-300.

6. Walker BF. The prevalence of low back pain: a systematic review of the literature from 1966 to 1998. J Spinal Disord. 2000;13(3):205-17.

7. Maetzel A, Li L. The economic burden of low back pain: a review of studies published between 1996 and 2001. Best Pract Res Clin Rheumatol. 2002;16(1):23-30.

8. Chiavenato I. Recursos humanos: o capital humano das organizações. 8. ed. São Paulo: Atlas; 2004.

9. Fundação Européia para a Melhoria das Condições de Vida e de Trabalho. A prevenção do absenteísmo no trabalho: sinopse de uma investigação. Luxemburgo: Serviço das Publicações Oficiais das Comunidades Européias; 1997.

10. Permanent Commission and International Association on Occupational Health. Sub-committee on absenteeism: draft recommendations. Br J Ind Med. 1973;30(4):402-3.

11. Quick TC, Lapertosa JB. Análise do absenteísmo em usina siderúrgica. Rev Bras Saude Ocup. 1982;40 (10):62-7.

12. Ghaffari M, Alipour A, Farshad AA, Jensen I, Josephson $M$, Vingard E. Low back pain among Iranian industrial workers. Occup Med. 2006;56(7):455-60.

13. Danatro D. Ausentismo laboral de causa médica em uma instituición pública: Montevideo: 1994-1995. Rev Med Uruguay. 1997;13(2):101-9.

14. Gomero-Cuadra R, Llap-Yesan C. Absentismo laboral de origem médica em el hospital Toquepala en el 2001. Rev Med Hered. 2004;15(2):96-101.

15. Santos JP. Absenteísmo-doença na prefeitura municipal de Porto Alegre, Rio Grande do Sul, Brasil. Rev Bras Saude Ocup. 2010;35(121):148-56.

16. Silva LS, Pinheiro TMM, Sakurai E. Perfil de absenteísmo em um banco estatal em Minas Gerais: análise no período de 1998 a 2003. Cienc Saude Colet. 2008; 13(Supl. 2):2049-58.
17. Waddell G, Burton AK. Occupational health guidelines for the management of low back pain at work: evidence review. Occup Med. 2001;51(2):124-35.

18. Sala A, Carro ARL, Correa NA, Seixas PHD. Licenças médicas entre trabalhadores de Secretaria de Estado de Saúde de São Paulo no ano de 2004. Cad Saude Publica. 2009;25(10):2168-78.

19. Cunha JB, Blank VLG, Boing AF. Tendência temporal de afastamento do trabalho em servidores públicos (1995-2005). Rev Bras Epidemiol. 2009;12(2):226-36.

20. Gehring Jr. G, Corrêa Filho HR, Vieira Neto JD, Vieira SVR. Absenteísmo-doença entre profissionais de enfermagem da rede básica do SUS Campinas. Rev Bras Epidemiol. 2007;10(3):401-9.

21. Inoue KC, Matsuda LM, Silva DMPP, Uchimura TT, Mathias TAF. Absenteísmo-doença da equipe de enfermagem em unidade de terapia intensiva. Rev Bras Enferm. 2008;61(2):209-14.

22. Costa FM, Vieira MA, Sena RR. Absenteísmo relacionado a doenças entre membros da equipe de enfermagem de um hospital escola. Rev Bras Enferm. 2009; 62(1):38-44.

23. Stanton TR, Henschke N, Maher CG, Refshauge KM, Latimer J, McAuley JH. After an episode of acute low back pain, recurrence is unpredictable and not as common as previously thought. Spine. 2008;33(26): 2923-28.

24. Mielenz TJ, Garrett JM, Carey TS. Association of psychosocial work characteristics with low back pain outcomes. Spine. 2008;33(11):1270-5.

25. Wasiak R, Kim J, Pransky G. Work disability and costs caused by recurrence of low back pain: longer and more costly than in first episodes. Spine. 2006; 31(2):219-25.

26. Pincus T, Burton AK, Vogel S, Field AP. A systematic review of psychological factors as predictors of chronicity/disability in prospective cohorts of low back pain. Spine. 2002;27(5):E109-20.

27. Gheldof ELM, Vinck J, Vlaeyen JWS, Hidding A, Crombez G. Development of and recovery from short-and longterm low back pain in occupational sittings: a prospective cohort study. Eur J Pain. 2007;11(8):841-54. 
28. Steenstra IA, Knol DL, Bongers PM, Anema JR, Mechelen WV, Vet HCW. What works best for whom? An exploratory, subgroup analysis in a randomized, controlled trial on the effectiveness of a workplace intervention in low back pain patients on return to work. Spine. 2009;34(12):1243-9.

29. Tveito TH, Hysing M, Eriksen HR. Low back pain interventions at the workplace: a systematic literature review. Occup Med. 2004;54(1):3-13.

30. Henrotin YE, Cedraschi C, Duplan B, Bazin T, Duquesnoy B. Information and low back pain management. Spine. 2006;31(11):E326-34.

31. Munch-Hansen T, Wieclaw J, Agerbo E. Sickness absence and workplace levels of satisfaction with psychosocial work conditions at public service workplaces. Am J Ind Med. 2009;52(2):153-61.
32. Bergstrom G, Bodin L, Hagberg J, Lindh T, Aronsson $\mathrm{G}$, Josephson M. Does sickness presenteeism have an impact on future general health?. Int Arch Occup Environ Health. 2009;82(10):1179-90.

33. Bergstrom G, Bodin L, Hagberg J, Aronsson G, Josephson M. Sickness Presenteeism today, Sickness absenteeism tomorrow? A prospective study on sickness presenteeism and future sickness absenteeism. J Occup Environ Med. 2009;51(6):629-38.

34. Caverley N, Cunningham JB, MacGregor JN. Sickness presenteeism, sickness absenteeism. And health following restructuring in a public service organization. J Manage Stud. 2007;44(2):304-19.

35. Ricci JA, Stewart WF, Chee E, Leotta C, Foley K, Hochber MC. Back pain exacerbations and lost productive time costs in United States workers. Spine. 2006;31(26):3052-60.

Received: 07/01/2013

Recebido: 01/07/2013

Approved: 02/27/2014

Aprovado: 27/02/2014 